\title{
PENGEMBANGAN MEDIA PEMBELAJARAN ANIMASI 2D PADA MATA PELAJARAN FISIKA KELAS X DI SMA NEGERI 1 SAWAN
}

\author{
Ni Luh Dinda Ajeng Wahyuni ${ }^{1}$, Nyoman Sugihartini ${ }^{2}$, I Gede Partha Sindu ${ }^{3}$ \\ Program Studi Pendidikan Teknik Informatika \\ Jurusan Teknik Informatika \\ Fakultas Teknik dan Kejuruan \\ Universitas Pendidikan Ganesha \\ Singaraja,Bali \\ Email : niluhdindaajeng27@gmail.com ${ }^{1}$, sugihartini@undiksha.ac.id ${ }^{2}$, partha.sindu@undiksha.ac.id ${ }^{3}$
}

\begin{abstract}
Abstrak - Pengembangan media pembelajaran sangat diperlukan pada mata pelajaran fisika di SMA Negeri 1 Sawan. Hal tersebut dikarenakan dalam proses pembelajaran guru masih menggunakan metode ceramah. Sekolah menyediakan buku paket pelajaran sebagai sumber belajar pokok dan lembar kerja siswa (LKS) sebagai penunjang proses pembelajaran. Penggunaan media sebagai pembelajaran masih terbatas pada media power point dan video yang diambil di internet. Untuk mengatasi masalah ini, dikembangkan media pembelajaran animasi 2D untuk kelas $X$ untuk memfasilitasi proses belajar mengajar dan memotivasi siswa dalam suasana pembelajaran menjadi lebih menyenangkan. Metode yang digunakan dalam penelitian ini adalah penelitian dan pengembangan (research and development), untuk mengembangkan media pembelajaran animasi 2D pada mata pelajaran fisika. Model yang akan digunakan adalah model Multimedia Development Life Cycle, yang memiliki 6 tahapan yaitu concept, design, material collecting, assembly, testing dan distribution. Hasil penelitian ini berupa sebuah media pembelajaran yang baik dikemas dalam bentuk CD. Terdapat beberapa pengujian untuk mengetahui kelayakan media, terdiri uji ahli isi dengan hasil $100 \%$, uji ahli media $100 \%$, uji efektifitas $74,73 \%$ termasuk dalam kriteria tinggi, uji respon guru $88 \%$ dan uji respon siswa diperoleh $81,02 \%$ termasuk dalam kriteria baik.
\end{abstract}

Kata Kunci : Pelajaran Fisika, Media Pembelajaran, Animasi 2D, Model MDLC

Abstract-He development of instructional media was needed in physics subjects at SMA Negeri 1 Sawan. It was because the teacher still uses the lecture method in the teaching process. The school provided textbooks as a source and student worksheets (LKS) to support the learning process. The usage of media of learning was limited to PowerPoint, and videos are taken from the internet. The solve this problem, 2D animation learning media was developed for class $X$ to facilitate the teaching and learning process and motivate students to have a more enjoyable learning atmosphere. This research used the research and development method to develop $2 D$ animation learning media in physics subjects. It used the Multimedia Development Life Cycle model, which has six stages: concept, design, material collecting, assembly, testing, and distribution. The result of this study was a learning media in the form of a CD. There were several tests to determine the feasibility of the press, consisting of the content expert test with $100 \%$ results, $100 \%$ media expert test, $74,73 \%$ effectivenss test included in the high criteria, $88 \%$ teacher response test, and student response test obtained $81,02 \%$ included in right measures.

Keywords: Physics, Learning Media, 2D Animation, MDLC Model

\section{PENDAHULUAN}

Perkembangan teknologi dalam dunia pendidikan saat ini sangat berkembang pesat. Teknologi informasi dalam dunia pendidikan memiliki peranan yang sangat penting dalam meningkat kualitas sumber daya manusia (SDM),khususnya SDM di Indonesia. Meningkatkan kualitas sumber daya manusia, perlu dukungan dari berbagai aspek kehidupan, salah 
e-ISSN: 2685-7006 | p-ISSN: $2252-9063$

Kumpulan Artikel Mahasiswa Pendidikan Teknik Informatika

(KARMAPATI)

Volume 10, Nomor 2,Tahun 2021

satunya yaitu aspek pendidikan [6]. Pendidikan merupakan salah satu aspek kehidupan, salah satunya terpenting yang harus dikembangkan. Menurut Undang-Undang No.20 Tahun 2003 tentang Sistem pendidikan merupakan usaha sadar dan terencana untuk mewujudkan suasana belajar dan proses pembelajaran agar peserta didik secara aktif mengembangkan potensi dirinya untuk memiliki kekuatan spiritual keagamaan, pengendalian diri, kepribadian, kecerdasan, akhlak mulia, serta keterampilan yang diperlukan dirinya, masyarakat, bangsa dan negara.

Media pembelajaran adalah alat atau perantara di dalam proses belajar mengajar untuk membangkitkan keinginan dan minat yang baru, membangkitkan motivasi dan rangsangan kegiatan belajar, dan sangat berpengaruh terhadap psikologis. Penggunaan media pembelajaran dalam proses pembelajaran sangat membantu keefektifan proses pembelajaran dan penyampaian materi pembelajaran [1]. Salah satunya adalah menggunakan media animasi. Animasi merupakan suatu media pembelajaran yang menarik berbentuk visual gerak. Media pembelajaran animasi dapat meningkatkan minat dan pemahaman belajar pada materi tertentu misalnya dalam mata pelajaran fisika.

Fisika merupakan mata pelajaran yang ada di jurusan IPA yang mempelajari sifat dan fenomena alam atau gejala alam serta seluruh interaksinya yang ada di dalamnya. Tujuan dari mempelajari fisika adalah agar manusia dapat mengenal bagian-bagian dari benda, memahami interaksi antar benda dan menjelaskan fenomena-fenomena yang terjadi [8].

Berdasarkan hasil observasi dan wawancara dengan guru mata pelajaran Fisika di SMA Negeri 1 Sawan adapun informasi yang diperoleh yaitu peserta didik hanya belajar menggunakan buku paket dan lembar kerja siswa (LKS) sebagai sumber belajar pokok dan sebagai penunjang. Sekolah menyediakan sarana media belajar seperti LCD dan proyektor. Namun penggunaan LCD dan proyektor masih jarang dilakukan dan penggunaannya masih terbatas pada media power point dan video yang di ambil di internet. Kadang video yang diambil di internet pembahasan materinya tidak sesuai dengan kurikulum. Pada pembelajaran Fisika guru cenderung menerapkan pendekatan atau metode ceramah. Sehingga peserta didik terkadang bosan dengan metode yang digunakan guru dalam mengajar.

Berdasarkan hasil observasi awal dengan menggunakan angket analisis kebutuhan peserta didik dalam pengembangan media pembelajaran animasi 2 dimensi pada mata pelajaran Fisika kelas X di SMA Negeri 1 Sawan, Berdasarkan hasil observasi awal dengan menggunakan angket analisis kebutuhan siswa, yang dibagikan kepada 35 siswa kelas $\mathrm{X}$ MIPA di SMA Negeri 1 Sawan, dimana hasil dari angket tersebut bertujuan untuk mengetahui persentase dari tiap indikator mengenai kebutuhan peserta didik terhadap media pembelajaran animasi pada mata pelajaran fisika yang akan dikembangkan oleh peneliti diantaranya : 1) pada indikator pemahaman peserta didik terhadap pembelajaran fisika diperoleh $77 \%$ peserta didik menyatakan setuju jika peserta didik kurang memahami pembelajaran fisika dan dalam pembelajaran fisika harus terdapat contoh-contoh gambar dan video agar peserta didik tidak merasa bosan, 2) pada indikator ketertarikan peserta didik terhadap pembelajaran fisika diperoleh sebanyak $76 \%$ peserta didik menyatakan tertarik jika pembelajaran fisika menggunakan media animasi dalam proses pembelajaran, 3) pada indikator motivasi peserta didik dalam pembelajaran diperoleh sebesar $85 \%$ peserta didik menyatakan media pembelajaran animasi dapat meningkatkan motivasi belajar peserta didik pada mata pelajaran fisika, 4) pada indikator materi pembelajaran untuk mengetahui tingkat kesulitan pemahaman peserta didik diperoleh sebesar $72 \%$ peserta didik menyatakan mata pelajaran fisika susah dipahami jika dijelaskan dengan teori saja, 5) pada indikator media pembelajaran untuk mengetahui media pembelajaran yang digunakan guru,diperoleh sebesar $77 \%$ peserta didik setuju guru masih menggunakan media yang tidak menarik, dan 6) pada indikator sarana pembelajaran diperoleh hasil sebesar $85 \%$ peserta didik menyatakan sarana pembelajaran di SMA Negeri 1 Sawan tergolong sangat baik.

Berdasarkan permasalahan yang terjadi dan beberapa solusi yang pernah ditawarkan peneliti sebelumnya perlu adanya media untuk menunjang proses pembelajaran fisika. Dalam rancangan membangun media pembelajaran peneliti berencana mengembangan media dengan judul "Pengembangan Media Pembelajaran Animasi 2 Dimensi Pada Mata Pelajaran Fisika Kelas X di SMA Negeri 1 Sawan”

\section{KAJIAN TEORI}

\subsection{Media Pembelajaran}

\section{a. Pengertian Media Pembelajaran}

Media pembelajaran adalah media yang digunakan dalam proses belajar mengajar. Media pembelajaran juga dapat membangkitkan minat, motivasi dan rangsangan dalam proses belajar. Selain itu media pembelajaran dapat membantu peserta didik dalam meningkatkan pemahaman, menyajikan materi dengan lebih menarik [1].

b. Fungsi Media Pembelajaran 


\section{KARMAPคTI}

1. Sebagai media untuk penyalur, penyampai, penghubung pesan atau pengetahuan dari pebelajar kepada pembelajar.

2. Sebagai media untuk memperjela arti kata, istilah, tanda atau simbol.

3. Sebagai media untuk menangkap, menyimpan dan menampilkan kembali suatu objek.

4. Sebagai media untuk menampilkan kembali objek.

5. Sebagai menampilkan suatu objek atau kejadian yang dapat menjangkau pengamat yang sangat besar dalam kawasan yang sangat luas

6. Sebagai media untuk meningkatkan keterampilan fisik peserta didik.

\subsection{Teori Belajar Kognitivistik}

Teori Belajar Kognitivistik merupakan teori belajar yang lebih menekankan proses belajar daripada hasil belajar. Teori belajar ini melibatkan proses berpikir yang kompleks [7].

\subsection{Storyboard}

Storyboard adalah bentuk sketsa gambar yang disusun secara berurutan sesuai naskah cerita. Storyboard juga dapat menyapaikan ide cerita kepada orang lain lebih mudah dan membuat seseorang membayangkan sebuah cerita dengan mengikuti gambar-gambar yang sudah diberikan [9].

\subsection{Animasi}

1. Pengertian Animasi

Animasi merupakan teknik pembuatan sebuah karya audio visual untuk menghasilkan sebuah urutan gambar yang membentuk satu adegan. Kelebihan animasi 2D yaitu dapat menyampaikan dan menjelaskan informasi yang rumit menjadi wujud yang lebih sederhana dalam bentuk media visual dan audio [5].

2. Jenis-Jenis Animasi Jenis-jenis animasi sebagai berikut
a. Animasi 2 Dimensi
b. Animasi 3 Dimensi
c. Animasi Stop Motion

3. Prinsip-Prinsip Animasi

Berikut 12 prinsip animasi yaitu:
a. Squash and Stretch
b. Anticipation
c. Staging
d. Straight ahead action \& Pose to Pose
e. Follow Through \& Overlapping Action
f. Slow In and Slow Out
g. Arc
h. Secondary Action
i. Timing
j. Exaggeration
k. Solid Drawing
1. Appeal

\subsection{Mata Pelajaran Fisika}

Kata fisika berasal dari bahasa yunani "physic" yang artinya alam. Fisika adalah ilmu pengetahuan yang mempelajari tentang sifat dan fenomena-fenomena alam atau gejala-gejala alam serta seluruh interaksinya. Fisika menjadi ilmu dasar karena berhubungan langsung dengan perilaku dan struktur benda, khususnya benda mati yang berada di alam. Fisika juga sebagai dasar dari berbagai pengembangan ilmu dan teknologi [8].

\subsection{Perangkat Lunak}

1. Adobe Premiere Pro CS6 dikembangkan oleh adobe system untuk editing video

2. Adobe Illustrator merupakan program untuk mengolah serta mengedit desain atau gambar vector

3. Adobe After Effect CS6 digunakan dalam pembuatan video, multimedia, film dan web.

4. Adobe animate $\mathrm{CC}$ adalah salah satu software yang dapat membuat berbagai macam animasi.

5. Adobe Audition CS6 adalah suatu program yang dibuat oleh adobe system. Adobe audition digunakan untuk merekam suara dan menyunting hasil rekaman untuk dijadikan sound efek dan backsound.

6. Adobe Photoshop CS6 digunakan untuk pengeditan foto, gambar dan pembuatan effect.

\section{METODOLOGI PENELITIAN}

Penelitian ini dilaksanakan menggunakan metode penelitian dan pengembangan atau Research and Development (R\&D). Research and Development adalah metode penelitian yang digunakan untuk menghasilkan sebuah produk tertentu dan menguji keefektifan sebuah produk tersebut (Sugiyono, 2009). Penelitian ini bertujuan untuk mengembangkan sebuah media animasi 2 dimensi pada mata pelajaran fisika kelas $\mathrm{X}$ di SMA Negeri 1 Sawan.

Model pengembangan yang digunakan dalam penelitian ini yaitu model Multimedia Development Life Cycle (MDLC) model ini salah satu model untuk pengembangan multimedia. Model pengembangan multimedia yang terdiri dari enam tahapan yaitu concept, design, material collecting, assembly, testing, dan distribution. 


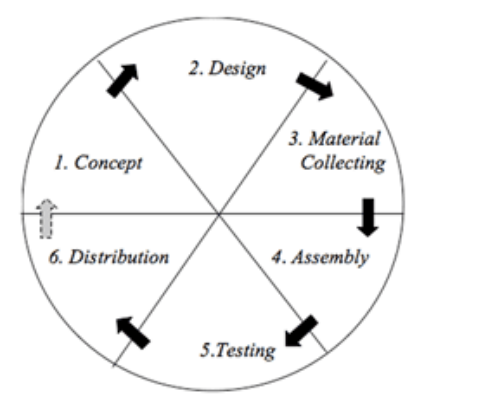

Gambar 1. Tahapan Model MDLC Sumber : (Mustika,dkk. 2018)

\section{Pengonsepan (Concept)}

Pada tahapan ini merupakan tahap awal dari pengembangan video pembelajaran. Pada tahap konsep ini untuk menentukan ide media yang akan dikembangkan yaitu dengan melakukan observasi lapangan dan mengumpulkan referensi mengenai pokok bahasan yang akan diambil. Dari hasil observasi lapangan peneliti memperoleh beberapa aspek analisis konsep kebutuhan yaitu: menganalisa kurikulum yang berlaku dan menganalisa media. Menganalisa kurikulum yang berlaku di SMA Negeri 1 Sawan. Setelah mengetahui kurikulum yang berlaku maka dapat diketahui kompetensi apa yang ingin dicapai pada mata pelajaran fisika. Pada tahapan ini peneliti akan mengkaji indikator dan kompetensi dasar mata pelajaran fisik yang akan dijadikan sebagai acuan media pembelajaran animasi 2D. Menganalisa media merupakan pemaksimalan teknologi komputer di dalam bidang multimedia untuk meningkatkan pembelajaran fisika dengan media pembelajaran animasi 2D. Media animasi 2D ini dibuat berupa video menggunakan adobe animate CC, adobe after effect CS6, adobe audition CS6 dan adobe premiere pro CS6.

\section{Perancangan (Design)}

Pada tahapan ini dilakukan perancangan dari media pembelajaran animasi 2D. Tahapan desain ini merupakan lanjutan dari tahapan konsep, dimana hasil dari analisis media direpresentasikan ke dalam bentuk desain agar dapat diimplementasikan ke tahap berikutnya menjadi sebuah media pembelajaran animasi 2D berupa video. Tahapan desain terdiri dari penyusunan kerangka struktur isi dan penyusunan garis-garis besar dari media yang dalam hal ini berbentuk video animasi 2D. Pada tahap ini, pembuatan media pembelajaran masuk pada pra produksi. Hal yang dilakukan pada tahap pra produksi yaitu:

1. Ide cerita

Ide cerita merupakan hal yang paling utama untuk mengembangkan sebuah media pembelajaran. Ide cerita yang sudah terkumpul akan dituangkan dalam bentuk cerita. Ide cerita yang disusun sebelumnya akan diimplementasikan menjadi video.

2. Storyboard

Storyboard merupakan rancangan gambar yang akan disusun secara berurutan sesuai dengan naskah cerita. Hasil dari perancangan storyboard akan menjadi acuan untuk pembuatan tampilan pada tahap implementasi.

3. Pada tahap perancangan karakter ini, akan di rancang karakter yang sesuai dengan video pembelajaran yang akan di buat

3. Pengumpulan bahan (Material Collecting)

Pada tahapan ini adalah tahapan untuk pengumpulan bahan yang dikumpulkan berupa asset animasi $2 \mathrm{D}$, video, audio, dan mengumpulkan bahan-bahan materi yang akan ditampilkan dalam media pembelajaran. Hasil dari material collecting pada perancangan penelitian media animasi 2D berupa video mata pelajaran fisika terdiri dari pembuatan karakter 2D, Pemilihan pengisi suara untuk karakter 2D, Pembuatan asset dan pembuatan animasi 2D.

4. Pembuatan (Assembly)

Pada tahapan pembuatan (Assembly), penelitian pengembangan media pembelajaran animasi 2D menggunakan 2 tahapan, yaitu tahap pra produksi dan pasca produksi. Tahap pra produksi terdiri dari proses pembuatan karakter dan background 2D yang akan dibuat di aplikasi adobe illustrator. Proses desain animasi dibuat menggunakan aplikasi adobe animate. Setelah proses pembuatan animasi selesai selanjutnya proses penggabungan dubbing dan animasi dilakukan menggunakan aplikasi adobe premiere pro. Tahap selanjutnya merupakan tahap pasca produksi yang terdiri dari pembuatan seluruh objek, pengumpulan bahan, audio editing, dan video editing.

5. Pengujian (Testing)

Pada tahap ini dilakukan pengujian pada media yang dibuat. Tahapan pengujian ini dilakukan tidak setelah media jadi keseluruhannya, melainkan dilakukan tiap scene dalam sebuah video pembelajaran agar hasilnya sesuai dengan standar produksi video. Pada tahap testing, terdapat Uji Ahli Isi, Uji Ahli Media, Uji Efektivitas, Uji 


\section{KARMAPคTI}

Respon Siswa. Pengujian tersebut dibuatkan sebuah instrumen penelitian. Instrumen penelitian merupakan sebuah alat yang digunakan dalam mengumpulkan data sebagai suatu bagian penting dalam penelitian. Instrumen yang digunakan dalam penelitian ini berupa angket untuk Ahli Isi, Ahli Media, dan Respon.

\section{Distribusi (Distribution)}

Pada tahap distribusi merupakan tahap akhir dalam sebuah pengembangan media pembelajaran animasi 2D. Setelah tahap pengujian selesai dan dinyatakan layak pakai, maka dilakukan tahap distribusi. Pada tahap ini, media yang telah dibuat akan disimpan dalam sebuah media penyimpanan berupa Compact Disk (CD) kemudian akan di distribusikan ke tempat penelitian yaitu di SMA Negeri 1 Sawan.

\section{HASIL}

\section{HASIL \& PEMBAHASAN}

Berdasarkan penelitian mengenai sebuah media pembelajaran animasi 2D pada mata pelajaran fisika kelas X di SMA Negeri 1 Sawan didapatkan hasil sebagai berikut:

\section{Hasil Tahap concept}

Pada tahap pengembangan media animasi 2 dimensi dengan pokok bahasan momentum dan impuls dalam pelajaran menggunakan metode penelitian Research and Development (R\&D) dengan menggunakan model pengembangan MDLC. Adapun hasil pengembangan media pembelajaran adalah sebagai berikut.

\section{A. Analisis Kurikulum}

Pada tahap ini untuk menganalisa kurikulum yang berlaku di SMA Negeri 1 Sawan. Setelah mengetahui kurikulum yang berlaku maka dapat diketahui kompetensi apa yang inigin dicapai pada mata pelajaran fisika, maka didapatkan ketepatan materi yang akan dikembangkan.

Pada tahap ini peneliti akan mengkaji indikator dan kompetensi dasar mata pelajaran fisika yang akan dijadikan sebagai acuan media pembelajaran.

Table 1. Analisis Kurikulum

\begin{tabular}{|l|l|l|}
\hline Kompetensi Dasar & \multicolumn{1}{|c|}{ Indikator } & \multicolumn{1}{|c|}{ Materi } \\
\hline 3.10 Menerapkan & 1.Menjelaskan & 1. Momentum \\
konsep momentum & konsep momentum & 2. Impuls \\
dan impuls, serta & 2.Menentukan & 3.Hubungan antara \\
hukum kekekalan & persamaan & impuls dan \\
momentum dalam & momentum & momentum \\
kehidupan sehari- & 3.Menjelaskan & \\
\hline
\end{tabular}

\begin{tabular}{|c|c|c|}
\hline \multirow[t]{4}{*}{ hari } & $\begin{array}{l}\text { konsep impuls } \\
\text { 4.Merumuskan } \\
\text { persamaan impuls } \\
\text { 5.Menghubungkan } \\
\text { antara impuls dan } \\
\text { perubahan } \\
\text { momentum }\end{array}$ & \\
\hline & $\begin{array}{l}\text { 1.Menjelaskan } \\
\text { bunyi hukum } \\
\text { kekekalan } \\
\text { momentum } \\
\text { 2.Menjabarkan } \\
\text { hukum kekekalan } \\
\text { momentum ke } \\
\text { persamaan } \\
\text { 3.Menerapkan } \\
\text { hukum kekekalan } \\
\text { momentum dalam } \\
\text { kehidupan sehari- } \\
\text { hari melalui } \\
\text { kegiatan proyek } \\
\text { memodifikasi } \\
\text { roket sederhana }\end{array}$ & $\begin{array}{l}\text { 1.Hukum } \\
\text { kekekalan } \\
\text { momentum }\end{array}$ \\
\hline & $\begin{array}{l}\text { 1.Menjelaskan } \\
\text { jenis-jenis } \\
\text { tumbukan } \\
\text { 2.Menjelaskan } \\
\text { konsep tumbukan } \\
\text { lenting sempurna } \\
\text { 3.Menentukan } \\
\text { persamaan } \\
\text { tumbukan lenting } \\
\text { sempurna } \\
\text { berdasarkan } \\
\text { hukum kekekalan } \\
\text { momentum dan } \\
\text { energi }\end{array}$ & 1.Tumbukan \\
\hline & $\begin{array}{l}\text { 4.Menjelaskan } \\
\text { konsep tumbukan } \\
\text { lenting sebagian } \\
\text { 5.Menjelaskan } \\
\text { persamaan } \\
\text { tumbukan lenting } \\
\text { sebagian }\end{array}$ & \\
\hline
\end{tabular}


e-ISSN: 2685-7006 | p-ISSN: $2252-9063$

Kumpulan Artikel Mahasiswa Pendidikan Teknik Informatika

(KARMAPATI)

Volume 10, Nomor 2,Tahun 2021

KARMAPATI

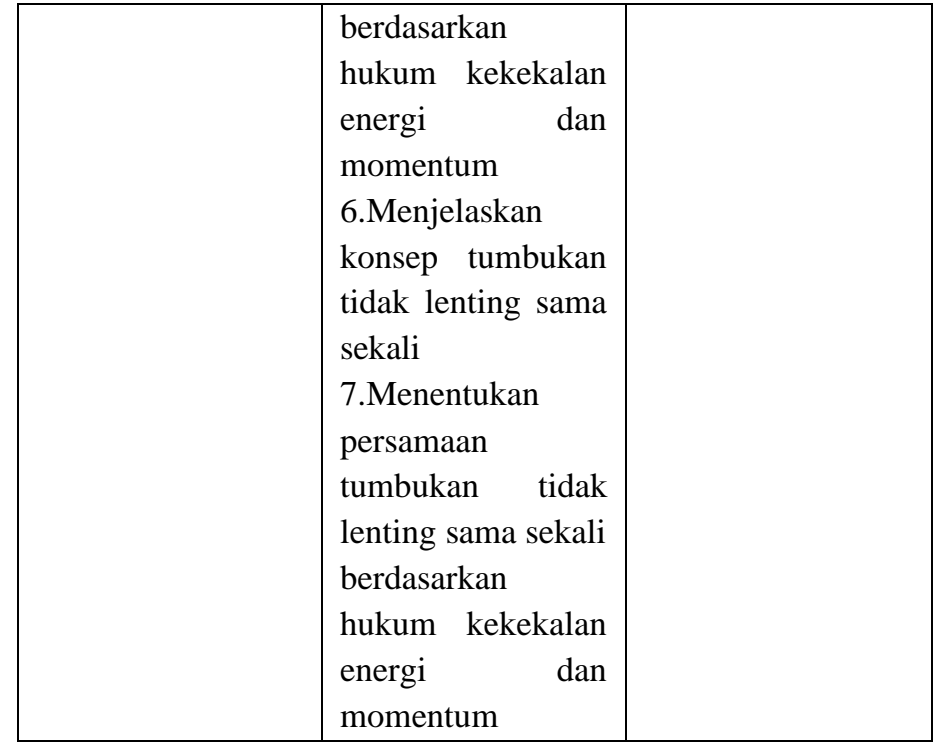

\section{B. Analisi Media}

Pada tahap ini menganalisa media untuk pemaksimalan teknologi komputer didalam proses peningkatan pembelajaran fisika dengan media pembelajaran animasi 2 dimensi , sehingga dapat dengan mudah dipahami oleh peserta didik. Media ini akan menjelaskan materi tentang momentum dan impuls pada mata pelajaran fisika. Berikut penjelasan terkait tahap konsep media animasi 2 dimensi tentang momentum dan impuls pada mata pelajaran fisika.

Table 2. Analisis Media

\begin{tabular}{|r|l|l|}
\hline \multicolumn{1}{|c|}{ No. } & \multicolumn{1}{|c|}{ Konsep } & \multicolumn{1}{|c|}{ Keterangan } \\
\hline 1. & Judul & $\begin{array}{l}\text { Pengembangan Media Pembelajaran } \\
\text { Animasi 2 Dimensi Pada Mata } \\
\text { Pelajaran Fisika Kelas X di SMA } \\
\text { Negeri 1 Sawan }\end{array}$ \\
\hline 2. & Pengguna & $\begin{array}{l}\text { Pengguna media pembelajaran } \\
\text { animasi 2 dimensi untuk guru yang } \\
\text { mengampu mata pelajaran fisika } \\
\text { kelas X di SMA Negeri 1 Sawan. }\end{array}$ \\
\hline 3 & Tujuan & $\begin{array}{l}\text { Tujuan pembuatan media ini yaitu } \\
\text { untuk membantu pendidik dan } \\
\text { peserta didik dalam proses } \\
\text { pembelajaran dan meningkatkan } \\
\text { motivasi belajar peserta didik. }\end{array}$ \\
\hline 4. & Jenis Media & $\begin{array}{l}\text { Jenis media pembelajaran animasi 2 } \\
\text { dimensi yang akan dibuat adalah } \\
\text { berupa video animasi 2 dimensi. }\end{array}$ \\
\hline 5. & Pedoman & \begin{tabular}{l} 
Isi materi pembelajaran mengacu \\
\hline
\end{tabular} \\
\hline
\end{tabular}

\begin{tabular}{|r|l|l|}
\hline & Materi & $\begin{array}{l}\text { pada buku yang diberikan oleh guru } \\
\text { mata pelajaran fisika kelas X di } \\
\text { SMA Negeri 1 Sawan }\end{array}$ \\
\hline 6. Audio & $\begin{array}{l}\text { Audio berformat .mp3 dan .wav } \\
\text { yang diambil dari berbagai sumber } \\
\text { dan hasil rekaman dubbing. }\end{array}$ \\
\hline 7. Video & $\begin{array}{l}\text { Menggunakan file yang berformat } \\
\text {.mp4 yang dibuat dengan Adobe } \\
\text { Premiere CS6,Adobe After Effects } \\
\text { CS6 dan Adobe Animation CC. }\end{array}$ \\
\hline Output & $\begin{array}{l}\text { Hasil akhir pengembangan media } \\
\text { pembelajaran animasi 2 dimensi ini } \\
\text { berupa kepingan CD/DVD atau } \\
\text { softcopy mp4 melalui flashdisk yang } \\
\text { akan diberikan ke pihak sekolah } \\
\text { tempat penelitian. }\end{array}$ \\
\hline
\end{tabular}

2. Hasil tahap perancangan (Design)

Pada tahap ini dilakukan perancangan dari media pembelajaran. Tahap desain merupakan tahapan lanjutan dari tahap concept, hasil analisis dari media ini akan direpresentasikan ke dalam bentuk desain yang nantinya bisa diimplementasikan ke tahap selanjutnya menjadi sebuah media pembelajaran. Pada tahap desain ini mendapatkan sebuah hasil berupa sinopsis materi pembelajaran, storyboard dan perancangan karakter.
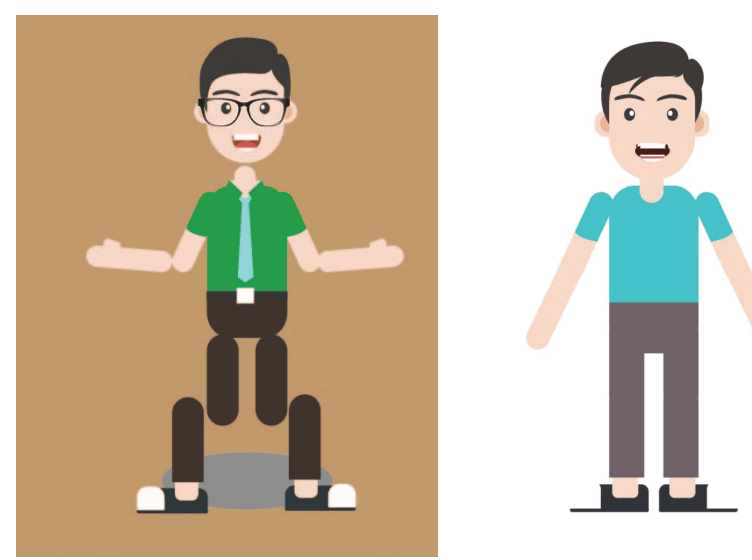

Gambar 2. Rancangan Karakter

\section{Hasil Tahap Pengumpulan Bahan (Material Collecting)}

Pada tahap ini, bahan yang dikumpulkan dalam pembuatan media berupa animasi 2 dimensi, gambar, 


\section{KคRmดคดT}

audio dan mengumpulkan bahan-bahan materi yang akan ditampilkan pada media pembelajaran

4. Hasil tahap Pembuatan (Assembly)

Pada tahap ini proses pembuatan media pembelajaran sesuai dengan storyboard yang telah dibuat sebelumnya 1. Proses Perekaman Audio (Dubbing)

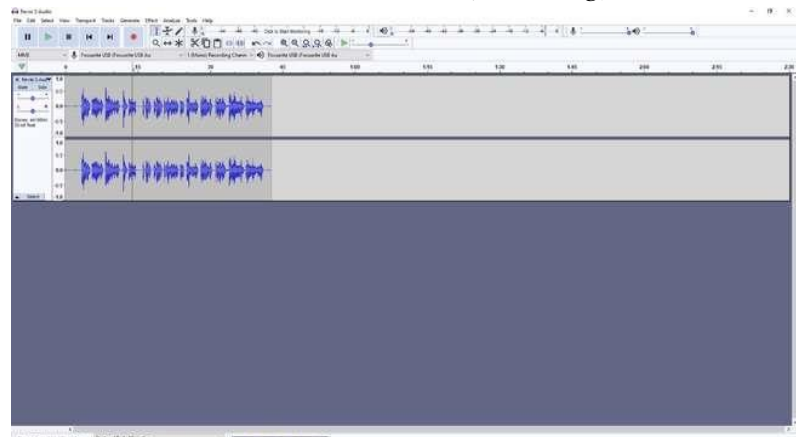

Gambar 3. Editing Audio

2. Proses Pembuatan Karakter 2D

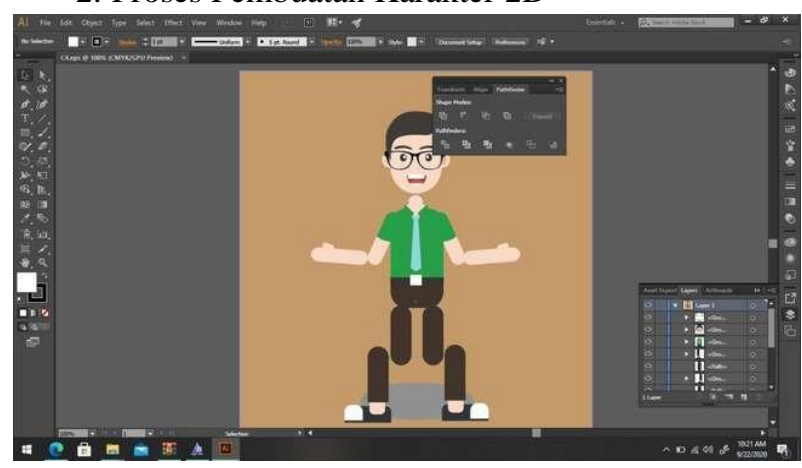

Gambar 4. Pembuatan Karakter

3. Desain Animasi 2D

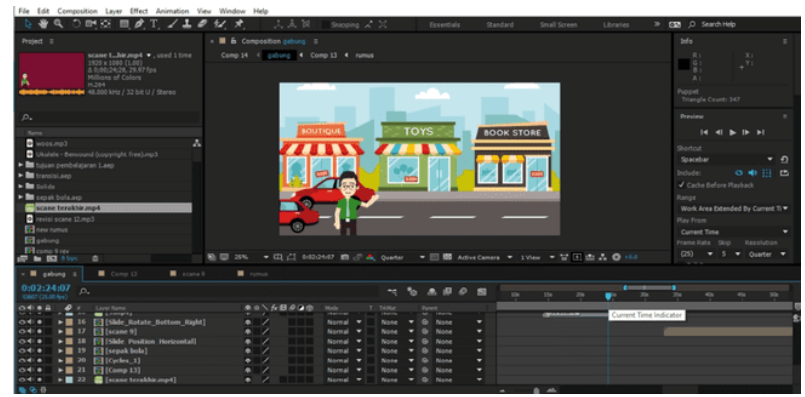

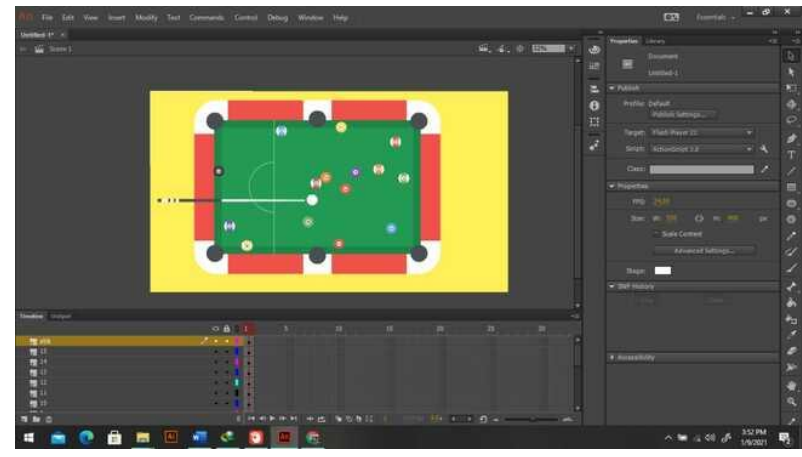

Gambar 5. Pembuatan Media

4. Penggabungan Media Pembelajaran

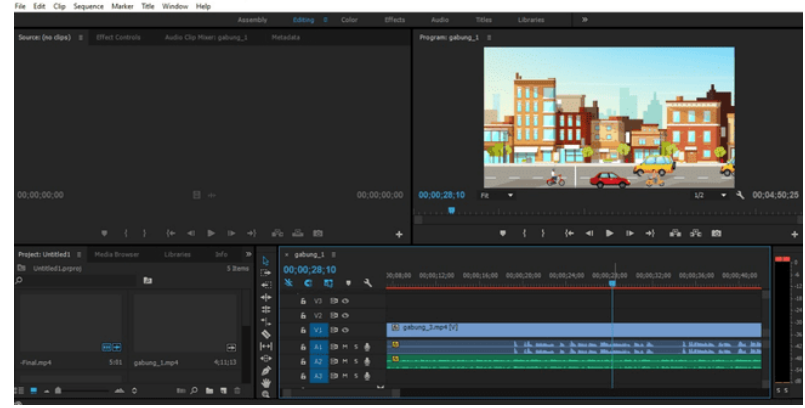

Gambar 6. Proses Penggabungan Media

5. Tampilan Judul Pada Media Pembelajaran

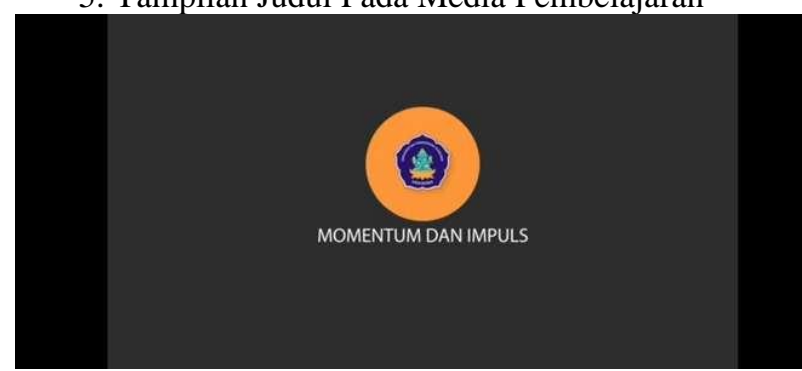

Gambar 7. Tampilan Judul Media Pembelajaran

6. Tampilan Indikator

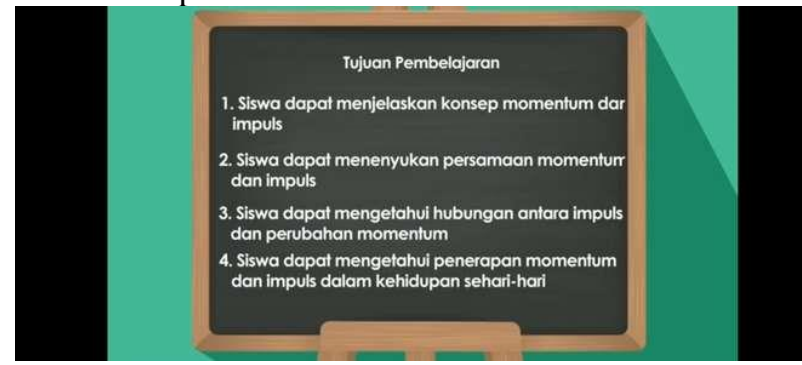

Gambar 8. Tampilan Indikator 
2685-7006|p-ISSN: 2252-9063

Kumpulan Artikel Mahasiswa Pendidikan Teknik Informatika

(KARMAPATI)

Volume 10, Nomor 2,Tahun 2021

\section{KARMAPคTI}

\section{Tampilan Materi Pembelajaran}

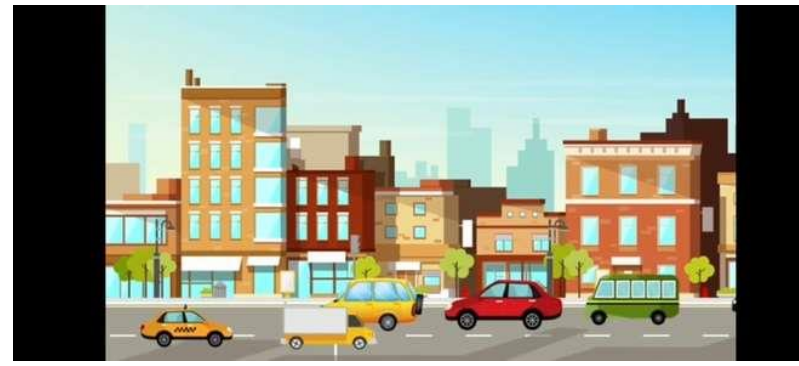

Gambar 9. Tampilan Materi Momentum dan Impuls

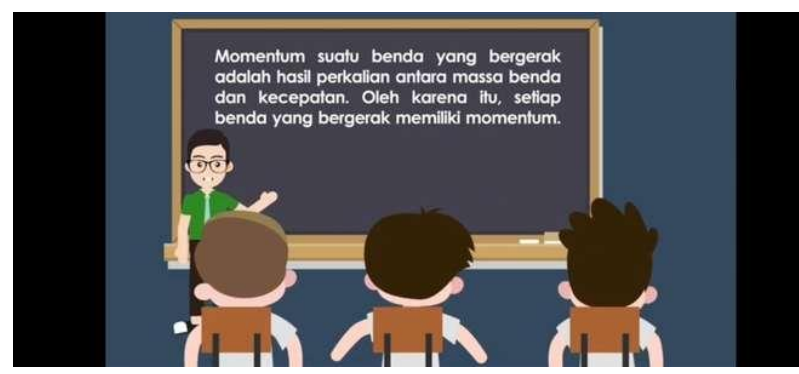

Gambar 10. Tampilan Materi Momentum

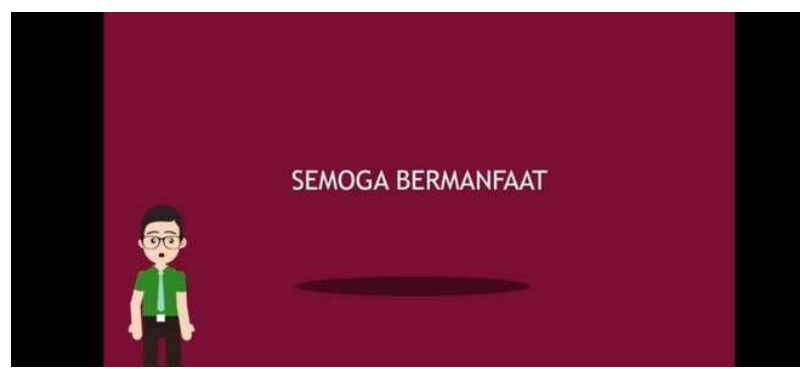

Gambar 11. Tampilan Penutup Media Pembelajaran

5. Hasil Tahap Pengujian (Testing)

A. Pengujian Alpha Testing

1. Uji Ahli Isi

Pada uji ahli isi bertujuan untuk mendapatkan data penelitian, pendapat dan saran mengenai keseluruhan isi yang ada pada media pembelajaran animasi 2D pada pelajaran fisika yang sudah dikembangkan. Uji ahli isi melibatkan 2 orang ahli, memperoleh hasil :

Validitas isi $=\frac{\mathrm{D}}{\mathrm{A}+\mathrm{B}+\mathrm{C}+\mathrm{D}}=\frac{10}{0+0+0+10}=\frac{10}{10}=$
Jadi produk pengembangan media pembelajaran animasi 2D pada mata pelajaran fisika memperoleh tingkat pencapaian "Sangat Tinggi", maka dapat disimpulkan bahwa tingkat pencapaian isi dari media pembelajaran animasi $2 \mathrm{D}$ pada mata pelajaran fisika kelas X layak untuk digunakan dalam pembelajaran fisika.

\section{Uji Ahli Media}

Pada uji ahli isi bertujuan untuk mendapatkan data penelitian, pendapat dan saran mengenai keseluruhan isi yang ada pada media pembelajaran animasi 2D pada pelajaran fisika yang sudah dikembangkan. Uji ahli media pembelajaran melibatkan dua dosen dari prodi pendidikan teknik informatika, hasil uji ahli media memperoleh hasil :

$$
\text { Validitas isi }=\frac{\mathrm{D}}{\mathrm{A}+\mathrm{B}+\mathrm{C}+\mathrm{D}}=\frac{10}{0+0+0+10}=\frac{10}{10}=
$$

Jadi produk pengembangan media pembelajaran animasi 2D pada mata pelajaran fisika memperoleh tingkat pencapaian "Sangat Tinggi", maka dapat disimpulkan bahwa tingkat pencapaian media pembelajaran animasi 2D pada mata pelajaran fisika kelas X layak untuk digunakan dalam pembelajaran fisika.

B. Pengujian Beta Testing

\section{Uji Respon Perorangan}

Uji respon perorangan dilakukan oleh siswa sebanyak 3 orang kelas X MIPA 2 SMA Negeri 1 Sawan dengan tingkat prestasi berbeda yaitu: tingkat prestasi rendah, sedang dan tinggi. Berdasarkan data respon yang diisi oleh tiga orang siswa maka dapat disimpulkan media pembelajaran animasi 2D pada mata pelajaran fisika kelas $\mathrm{X}$ adalah $80 \%$ sudah memenuhi kriteria BAIK. 
KARMAPคTI

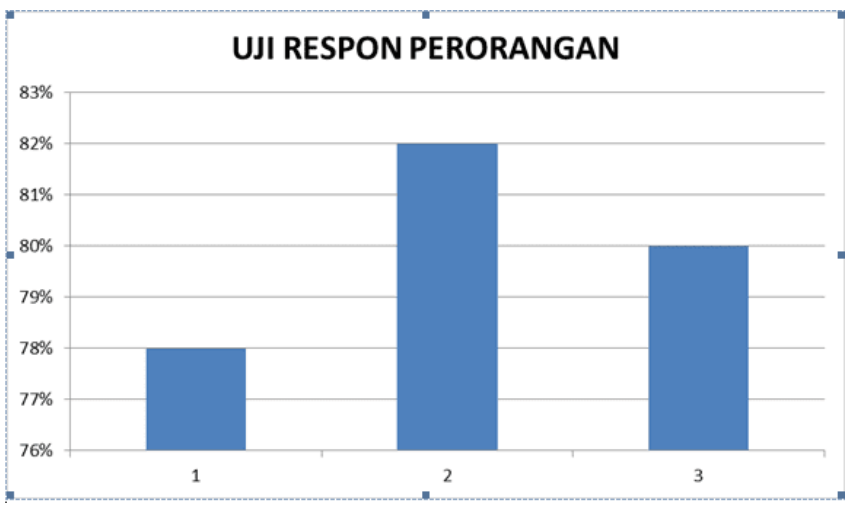

Gambar 12. Gambar Hasil Uji Respon Perorangan

2. Uji Respon Kelompok Kecil

Uji respon kelompok kecil dilakukan oleh siswa sebanyak 8 orang siswa kelas X MIPA 2 SMA Negeri 1 Sawan. Berdasarkan data respon yang diisi oleh kedelapan siswa makan dapat disimpulkan media pembelajaran animasi 2D pada mata pelajaran fisika kelas $\mathrm{X}$ adalah $82,25 \%$ sudah memenuhi kriteria BAIK.

\section{UJI KELOMPOK KECIL}

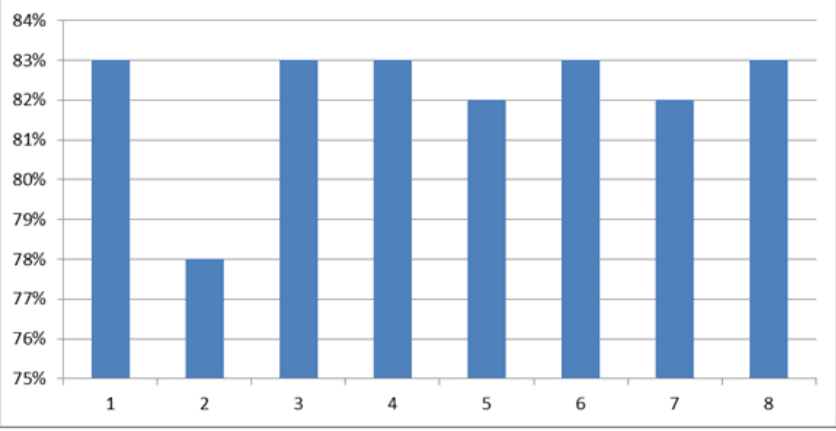

Gambar 13. Hasil Respon Kelompok Kecil

3. Uji Respon Uji Lapangan

Uji respon lapangan dilakukan oleh siswa sebanyak 34 orang siswa kelas X MIPA 1 . Berdasarkan data respon yang diisi oleh tiga puluh empat siswa maka dapat disimpulkan media pembelajaran animasi $2 \mathrm{D}$ pada mata pelajaran fisika untuk kelas $\mathrm{X}$ adalah $81,02 \%$ sudah memenuhi kriteria BAIK.

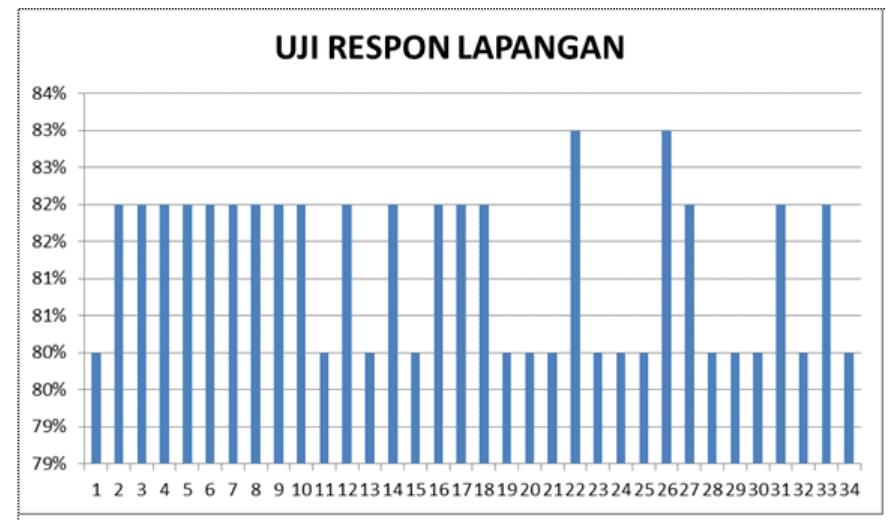

Gambar 14. Hasil Uji Respon Lapangan

\section{Uji Efektivitas}

Uji efektivitas dari media pembelajaran animasi 2D pada pelajaran fisika dengan memberikan pretest dan posttest untuk mengetahui peningkatan kemampuan siswa untuk memahami materi yang disampaikan melalui media pembelajaran berupa video. Pada pretest dan posttest peneliti membagikan pertanyaan berbentuk pilihan ganda yang terdiri dari 20 soal. Hasil analisis pretest dan posttest tersebut didapatkan rata-rata persentase kenaikan nilai sebesar 74,73\%. Sehingga tingkatan kenaikan hasil pretest dan posttest masuk dalam kriteria "Tinggi" yang berarti efektif untuk diterapkan dalam proses pembelajaran fisika materi momentum dan impuls.

5. Uji Respon Guru

Uji respon guru bertujuan dari tahap untuk mengetahui respon guru pengampu mata pelajaran fisika terhadap media pembelajaran animasi 2 dimensi. Pada tahap ini guru mengoperasikan media pembelajaran dan mengisi angket uji respon guru. Berdasarkan data respon guru yang diisi oleh guru mata pelajaran fisika maka dapat disimpulkan media pembelajaran animasi 2 dimensi untuk kelas $X$ adalah $88 \%$ sudah memenuhi kriteria BAIK.

\section{Hasil Tahap Distribusi (Distribution)}

Pada tahap ini media pembelajaran yang sudah selesai dibuat akan disimpan dalam sebuah media penyimpanan berupa Compact Disk (CD) kemudian akan didistribusikan ke tempat penelitian yaitu di SMA Negeri 1 Sawan untuk digunakan sebagaimana mestinya.. 


\section{PEMBAHASAN}

Pengembangan media pembelajaran animasi 2D pada mata pelajaran fisika ini bertujuan untuk membantu proses pembelajaran, dapat meningkatkan pemahaman dan motivasi belajar terhadap mata pelajaran fisika khususnya dalam pokok bahasan momentum dan impuls selama proses belajar mengajar di kelas. Hasil observasi dan wawancara dengan guru mata pelajaran fisika di SMA Negeri 1 Sawan bahwa dalam proses pembelajaran mata pelajaran fisika sekolah hanya menyediakan buku paket pelajaran sebagai sumber belajar pokok dan lembar kerja siswa (LKS) sebagai penunjang. Buku- buku tersebut bersifat informatif sehingga kurang menarik perhatian peserta didik dalam belajar fisika. Sekolah juga menyediakan sarana media belajar seperti LCD dan proyektor. Namun penggunaan LCD dan proyektor masih jarang dilakukan dan penggunaannya masih terbatas pada media power point dan video yang diambil di internet. Metode yang digunakan oleh guru selama proses pembelajaran adalah metode ceramah, hal ini menyebabkan proses pembelajaran berlangsung secara monoton dan membuat peserta didik merasa bosan dan kurang memperhatikan pelajaran yang disampaikan oleh guru.

Salah satu upaya untuk dapat mencapai proses pembelajaran ini yaitu dibutuhkan suatu media pembelajaran yang meningkatkan pemahaman, motivasi dan menarik perhatian siswa untuk belajar sehingga dapat menyampaikan materi dengan baik. Sebuah media pembelajaran animasi 2D pada mata pelajaran fisika untuk mata pelajaran fisika. Media pembelajaran animasi 2D ini sangat dibutuhkan di sekolah karena dapat menjadi media yang dapat membantu guru dalam menyampaikan materi pembelajaran. Dalam perancangan media ini menggunakan animasi 2D yang akan menjelaskan materi fisika khususnya pokok bahasan momentum dan impuls.

Pengembangan media pembelajaran animasi 2 dimensi ini menggunakan metode MDLC. Metode Multimedia Development Life Cycle (MDLC) terdiri dari 6 tahapan, yaitu Concept (pengonsepan), Design (perancangan), Material Collecting (pengumpulan bahan), Assembly (pembuatan), Testing (pengujian) dan Distribution (distribusi). Metode MDLC merupakan metode yang bersifat universal dan khusus untuk pengembangan multimedia.

Tahap concept ini, dimana pada tahap concept bertujuan untuk menentukan media pembelajaran yang dikembangkan, menentukan konsep materi dan konsep isi media pembelajaran.
Tahap kedua yaitu tahap design (perancangan), pada tahap ini meliputi perancangan media pembelajaran yang akan dikembangkan, dimana peneliti melakukan perancangan storyboard dan karakter. Perancangan storyboard menyesuaikan dengan konsep mata pelajaran fisika yang akan dipelajari, sehingga antara storyboard media pembelajaran dengan topik yang akan dibahas bisa sesuai. Perancangan karakter akan di rancang sesuai dengan media yang akan dibuat.

Tahap ketiga yaitu tahap material collecting (pengumpulan bahan). Pada tahap ini peneliti menggunakan berbagai bahan yang sudah tersedia di internet penyedia gratis. Pada tahap ini, bahan yang dikumpulkan berupa teks, gambar, animasi 2D, suara dan mengumpulkan materi yang akan ditampilkan di dalam media pembelajaran. Bahan-bahan yang digunakan diperoleh dari membuat sendiri dengan menggunakan adobe illustrator, adobe animate $\mathrm{CC}$, adobe audition, adobe after effect, adobe premiere dan beberapa bahan diambil dari internet kemudian akan diolah dengan aplikasi yang telah disebutkan sebelumnya.

Tahap keempat yaitu tahap assembly (pembuatan), pada tahap ini merupakan bagian dari proses pembuatan animasi, penyusunan teks, dan lain-lain. Pada tahap ini, media pembelajaran mulai dikembangkan sesuai dengan yang sudah ditetapkan pada design. Pembuat atau proses pembuatan media pembelajaran animasi 2D dibuat menggunakan adobe animate dan adobe after effect. Setelah proses pembuatan media selesai selanjutnya proses penggabungan dubbing dan animasi dilakukan menggunakan aplikasi adobe premiere pro.

Pada tahap Testing dilakukan pengujian media pembelajaran animasi 2D pada mata pelajaran fisika. Pengujian ini adalah proses menjalankan dan mengevaluasi sebuah media pembelajaran untuk menguji media tersebut apakah sudah memenuhi persyaratan atau belum. Pengujian ini untuk menentukan perbedaan antara hasil yang diharapkan dengan hasil yang sebenarnya. Tahap pengujian uji ahli yang pertama dilakukan yaitu uji ahli isi pembelajaran. Setelah uji ahli isi di lakukan, selanjutnya dilakukan uji ahli media, respon siswa, uji efektivitas dan uji respon guru, uji ahli respon guru dilakukan oleh guru pengampu mata pelajaran fisika. Hasil dari penilaian uji ahli isi dan uji ahli media dengan menggunakan uji Gregory yang bersumber dari angket tingkatan pencapaian dari media pembelajaran animasi 2D pada mata pelajaran fisika " Sangat Tinggi” tetapi terdapat beberapa saran revisi dari uji ahli untuk melaksanakan revisi pada pengembangan media pembelajaran. 
e-ISSN: 2685-7006 | p-ISSN: 2252-9063

Kumpulan Artikel Mahasiswa Pendidikan Teknik Informatika

(KARMAPATI)

Volume 10, Nomor 2,Tahun 2021

\section{KARMAPคTI}

Selanjutnya dilakukan uji perorangan, uji kelompok kecil dan uji lapangan. Subyek uji perorangan adalah 3 orang siswa kelas XI MIPA 2 SMA Negeri 1 Sawan, yang terdiri atas satu orang orang dengan prestasi belajar tinggi, satu orang dengan prestasi belajar sedang, dan satu orang dengan prestasi belajar rendah. Hasil uji perorangan rata-rata penilaian ketiga siswa adalah $80 \%$, jika dikonversikan ke dalam tabel respon siswa termasuk kategori "Baik". Hal ini mengindikasikan pengembangan media pembelajaran animasi $2 \mathrm{D}$ pada mata pelajaran fisika kelas $\mathrm{X}$ menunjukkan keberhasilan yang dibuktikan dengan terbantunnya siswa ke dalam proses pembelajaran.

Setelah uji perorangan selesai, maka dilanjutkan dengan uji kelompok kecil. Subjek uji kelompok kecil adalah 8 orang siswa kelas X MIPA 2 SMA Negeri 1 Sawan. Dari hasil angket uji yang diisi oleh delapan siswa, rata-rata penilaian adalah $82,25 \%$. Jika di konversikan ke dalam tabel respon siswa termasuk dalam kategori " Baik".

Berikutnya dilakukan uji lapangan, responden yang digunakan sebanyak 34 orang siswa kelas X MIPA 1 SMA Negeri Sawan. Hasil dari uji lapangan rata-rata penilaian seluruh siswa $81,02 \%$, jika dikonversi kedalam tabel konversi termasuk dalam kategori "Baik".

Selanjutnya dilakukan uji efektivitas dari media pembelajaran animasi 2D pada mata pelajaran fisik. Pada uji efektivitas dilakukan kepada 34 orang kelas X MIPA 1 SMA Negeri 1 Sawan dengan hasil analisis pretest dan posttest tersebut telah didapatkan masuk ke kriteria "Tinggi" . Dari hasil tersebut media ini sangat efektif untuk diterapkan dalam proses pembelajaran fisika materi momentum dan impuls.

Selanjutnya setelah melakukan uji efektivitas selesai, dilanjutkan dengan uji respon guru dari media pembelajaran animasi 2D pada mata pelajaran fisika. Subjek dari uji ini yaitu guru pengampu mata pelajaran fisika dengan hasil penilaian rata-rata penilaian hasil respon guru adalah dengan memenuhi kriteria "Baik"

Proses pengujian media pembelajaran mulai dari uji perorangan, uji kelompok kecil, uji lapangan dan uji efektivitas dilakukan secara online karena situasi pandemic virus covid-19 (corona) sehingga tidak memungkinkan untuk melakukan pengujian di sekolah. Pada saat pengujian, media pembelajaran berupa video dan disebar melalui link youtube dan siswa mengisi angket respon dan menjawab uji efektivitas melalui google form yang sudah disediakan.

Tahap selanjutnya adalah tahap Distribution, pada tahap ini media pembelajaran yang selesai dibuat akan disimpan dalam bentuk Compact Disk (CD) kemudian akan didistribusikan ke tempat penelitian yaitu SMA Negeri 1 Sawan.

Pengembangan media pembelajaran animasi 2D pada mata pelajaran fisika mata pelajaran fisika kelas $\mathrm{X}$ di SMA Negeri 1 Sawan memiliki beberapa kelebihan yang ditemukan selama proses pembuatannya. Adapun kelebihan dari media pembelajaran animasi 2D ini yaitu : 1). Fleksibilitas pembelajaran memudahkan guru dalam melakukan proses pembelajaran 2) materi yang berbentuk animasi membuat menarik perhatian peserta didik dalam proses pembelajaran 4) Contoh-contoh yang diberikan dijelaskan secara detail dan di berikan ilustrasinya.

\section{PENUTUP}

\section{A. Kesimpulan}

Kesimpulan yang diperoleh dari penelitian Pengembangan Media Pembelajaran Animasi 2D Pada Mata Pelajaran Fisika Kelas X SMA Negeri 1 Sawan adalah :

1. Pengembangan media pembelajaran animasi $2 \mathrm{D}$ pada mata pelajaran fisika menggunakan model Multimedia Development Life Cycle (MDLC) memiliki 6 tahapan yaitu tahap pengonsepan (concept), perancangan (design), pengumpulan bahan (material collecting), pembuatan (assembly), pengujian (testing), dan pendistribusian (distribution).

2. Respon siswa terhadap media animasi $2 \mathrm{D}$ pada mata pelajaran fisika kelas $\mathrm{X}$ sangat baik. Dilihat dari proses mengoperasikan media pembelajaran dan penyebaran angket terhadap siswa maka peneliti mendapatkan data hasil uji coba respon perorangan, uji coba respon kelompok kecil, uji coba lapangan dan uji coba respon guru dapat disimpulkan bahwa media pembelajaran animasi 2D pada mata pelajaran fisika untuk kelas $\mathrm{X}$ dikatakan berhasil atau sangat positif dalam mendukung proses pembelajaran dengan memberikan tanggapan sangat baik, yaitu hasil presentase uji respon perorangan sebanyak $80 \%$, uji respon kelompok kecil $82,25 \%$ dan uji respon lapangan $81,02 \%$.

\section{B. Saran}

Adapun beberapa saran yang disampaikan berdasarkan hasil penelitian dan pengembangan media pembelajaran animasi 2D pada mata pelajaran fisika kelas X di SMA Negeri 1 Sawan adalah :

1. Mengingat hasil pengembangan media pembelajaran animasi 2D pada mata pelajaran fisika kelas X layak 
digunakan maka dapat dimanfaatkan pada proses belajar mengajar sebagai media pembelajaran.

2. Media ini masih memiliki keterbatasan pada materi sehingga untuk pengembangan selanjutnya materi fisika dengan pokok bahasan momentum dan impuls dapat diperdalam dan diperbanyak untuk memberikan pengetahuan yang lebih untuk mata pelajaran fisika khususnya pelajaran fisika.

\section{REFERENSI}

[1] Arsyad, A. (2002). Media Pembelajaran. Jakarta: PT RajaGrafindo Persada.

[2] Dapoeranimasi. (2017). Animation \& Storytelling. Bandung: dapoeranimasi.com

[3] Djalle, Z. (2007). The Making 3D Animation Movie. Jakarta: Gramedia.

[4] H Rayandra, A. (2012). Kreatif Mengembangkan Media Pembelajaran. Jakarta: Referensi Jakarta.

[5] Herliyani, E. (2014). Animasi Dua Dimensi. Yogyakarta: GRAHA ILMU

[6] Isyarotullatifah, Santyasa, I., \& Agustini, K. (2019). Pengembangan Konten E-learning Simulasi Digital Berbasis Proyek untuk Siswa Kelas X di SMK Negeri 1 Kubutambahan. Jurnal Teknologi Pembelajaran Indonesia, Volume 9.

[7] Komara, E. (2014). Belajar dan Pembelajaran Interaktif. Badung: PT Refika Aditama.

[8] Nugroho, A. P., Indarti, \& Syifa, N. H. (2016). Fisika Peminatan Matematika dan Ilmu-Ilmu Alam untuk SMA/MA Kelas X. Surakarta: CV Mediatama.

[9] Purniasih, N. D. (2019). Pengembangan Media Pembelajaran Sumber Energi Berorientasi Gamifikasi untuk Siswa Kelas 4 North Bali Bilingual School. Singaraja: Undiksha.

[10] Satria, D. (2018). Video Animasi Multimedia Pembelajaran Keamanan Jaringan Komputer 2D. Jurnal Ilmu Komputer dan Bisnis, Volume 9. 